\title{
THE EFFECT OF DIFFERENT DOSES OF MAGNESIUM TREATMENTS ON THE FENUGREEK (TRIGONELLA FOENUM-GRAECUML.) YIELD
}

\section{Viktor József Vojnich, Judit Petö, András Palkovics, Attila Hüvely}

\author{
John von Neumann University \\ Faculty of Horticulture and Rural Development \\ Department of Agricultural Sciences \\ Kecskemét, Mészöly Gyula. Square 1-3. 6000 \\ vojnich.viktor@,kvk.uni-neumann.hu
}

\begin{abstract}
Fenugreek (Trigonella foenum-graecum L.) is an annual plant belonging to the legumes (Fabaceae) family. The plant is a Mediterranean one, native to the Mediterranean coast. It is a multi-use plant that is used as a herb, spice, and fodder plant. Fenugreek has high protein content and is well suited for feeding domestic and wild animals. Our open-field experiment was set up at the beginning of April 2018 in John von Neumann University, Faculty of Horticulture and Rural Development (Kecskemét). The treatments were: treatment $1=$ $150 \mathrm{~kg} / \mathrm{ha}$, treatment $2=300 \mathrm{~kg} / \mathrm{ha}$, treatment $3=450 \mathrm{~kg} /$ ha complex fertilizer. The treatments were carried out in plots of $50-50 \mathrm{~m}^{2}$. In the experiment, different nutrient supply treatments were set up to achieve the highest fresh biomass weight. The fertilizer used in the research was Novatec premium $\left(15 \mathrm{~N}-3 \mathrm{P}_{2} \mathrm{O}_{5}-20\right.$ $\mathrm{K}_{2} \mathrm{O}-2 \mathrm{MgO}$ ). When measuring fresh weight of fenugreek, the highest value was measured after $300 \mathrm{~kg} / \mathrm{ha}$ treatment $(14.45 \mathrm{~kg})$. The values of treatment $1(7.8 \mathrm{~kg})$ and the treatment $3(8.5 \mathrm{~kg})$ were almost the same. The highest dose of treatment $(450 \mathrm{~kg} / \mathrm{ha})$ resulted a decrease in the yield of $T$. foenum-graecum in our experiment.
\end{abstract}

Keywords: fenugreek (Trigonella foenum-graecum L.), yield, magnesium treatments, open-field, fertilizer

\section{INTRODUCTION}

Trigonella foenum-graecum L. is an annual plant belonging to the Fabaceae family of legumes (Fabales) (Provorov, 1985). Its leaves are like those of alfalfa, the leaves are scattered along the stem (VAN WYK, 2005). The plant is primarily self-pollinating but can also be cross-pollinating (SALVATORE, 1951). The plant is a Mediterranean one native to the Mediterranean coast. In countries of temperate climate, it is grown as a spring-sown plant. It is grown as a winter-sown plant in Egypt, Morocco and India (MAKAI et al., 1996). In Hungary, Sámuel Diószegi and Mihály Fazekas published in the Hungarian Phenomenon in 1807 as a wild herb (MAKAI and MAKAI, 2004). In Hungary before 1945 years, fenugreek was cultivated in the Southern part of the country as a horticultural crop. Later, in 1969-1970, the Agrobotany Institute in Tápiószele started the experimental cultivation. From 1982, research on the technology of cultivating fenugreek and the production of new, intensive varieties began in Mosonmagyaróvár. Then in 1987, a new Hungarian fenugreek variety has been bred, known under the name "Óvári-4". This variety was accepted by the state later, in 1994. It is currently cultivated on 100 hectares in Hungary.

The word foenum-graecum means "Greek hay" because the ancient Greeks used the plant to feed animals (MÁTHÉ, 1975). The Egyptians and Romans also called it by this name. Its medical value is also mentioned by Ebers papyrus, B.C. II. Millenium, used as anti-burn medicine (VARGA, 2001). Despite its many healing properties, its effect on humans was not used widespread until the Middle Ages. In modern science, it is only now that its advantages are being discovered. It is primarily used in veterinary medicine. It is mainly used to promote digestion, compress inflammation, fattening, and milk secretion. In North 


\section{4}

Review on Agriculture and Rural Development 2019 vol. 8 (1-2) ISSN 2677-0792

America, the settlers took fenugreek and used as fodder plant. The T. foenum-graecum crop has several advantages. Rhizobium meliloti is a nitrogen-binding bacterium on its roots that can bind about 70-90 kg/ha of nitrogen in the soil (MAKAI et al., 1996). Due to its high protein content, fenugreek is well suited for feeding domestic and wild animals.

It is grown for feeding purposes in the following countries: United States, Spain, Algeria, Tunisia, Egypt, Ethiopia, Afghanistan, Iran, India, China (KALMÁR, 1999). It is used as a green manure plant in the USA (California State), Chile and South France. Using as herbal medicine, it is grown in Central Europe. Fenugreek is grown in 2012 on about 96,000 hectares yearly in India.

In our experiment, different fertilization treatments were set to reach the highest volume of green mass and to follow the most advisable treatment dose in these circumstances.

\section{MATERIAL AND METHOD}

The experiment was carried out in the study garden of John von Neumann University, Faculty of Horticulture and Rural Development, in Kecskemét in 2018. Our test plant was fenugreek (Trigonella foenum-graecum L.). In the course of the open field trials different nutrient doses were applied. Seed sowing was placed in open field on $9^{\text {th }}$ of April 2018. The treatments were carried out in plots of 50-50 $\mathrm{m}^{2}$, according to the following methods: treatment $1=150 \mathrm{~kg} / \mathrm{ha}$; treatment $2=300 \mathrm{~kg} / \mathrm{ha}$; treatment $3=450 \mathrm{~kg} / \mathrm{ha}$ complex ground fertilizer. Mechanical weed control was applied. No chemicals or herbicides were applied. The harvest took place from June $25^{\text {th }}$ to July $9^{\text {th }}$.

The soil analysis of the experimental area (Table 1) and its evaluation was carried out by the Soil and Plant Testing Laboratory of the Faculty of Horticulture and Rural Development (Kecskemét).

Table 1. Soil characteristics of the experimental area (2018)

\begin{tabular}{|c|c|c|}
\hline Denomination & Measurement unit & Value \\
\hline $\mathrm{pH}_{\mathrm{KCL}}$ & - & 7.61 \\
\hline $\mathrm{K}_{\mathrm{A}}$ & - & 28 \\
\hline Water soluble salt & $\mathrm{m} / \mathrm{m} \%$ & $<0.02$ \\
\hline $\mathrm{Humus}$ & $\mathrm{m} / \mathrm{m} \%$ & 1.43 \\
\hline $\mathrm{CaCO}_{3}$ & $\mathrm{~m} / \mathrm{m} \%$ & 2.62 \\
\hline $\mathrm{NO}_{2}-\mathrm{NO}_{3}-\mathrm{N}$ & $\mathrm{mg} / \mathrm{kg}$ & 1.43 \\
\hline $\mathrm{P}_{2} \mathrm{O}_{5}$ & $\mathrm{mg} / \mathrm{kg}$ & 548 \\
\hline $\mathrm{K}_{2} \mathrm{O}$ & $\mathrm{mg} / \mathrm{kg}$ & 104 \\
\hline $\mathrm{Mg}$ & $\mathrm{mg} / \mathrm{kg}$ & 106 \\
\hline $\mathrm{Na}$ & $\mathrm{mg} / \mathrm{kg}$ & 6.61 \\
\hline $\mathrm{Cu}$ & $\mathrm{mg} / \mathrm{kg}$ & 13.1 \\
\hline $\mathrm{Mn}$ & $\mathrm{mg} / \mathrm{kg}$ & 55 \\
\hline $\mathrm{Zn}$ & $\mathrm{mg} / \mathrm{kg}$ & 9.72 \\
\hline $\mathrm{Fe}$ & $\mathrm{mg} / \mathrm{kg}$ & 64.1 \\
\hline $\mathrm{SO}$ & $\mathrm{mg} / \mathrm{kg}$ & 8.4 \\
\hline
\end{tabular}

Fertilizer used in the research was NovaTec premium $15-3-20(+2 \mathrm{MgO}+10 \mathrm{~S})+\mathrm{TE}$. Technical data of the fertilizer: $15.0 \%$ total nitrogen $(\mathrm{N}) ; 8.0 \%$ ammoniacal nitrogen $\left(\mathrm{NH}_{4}-\right.$ $\mathrm{N}) ; 7.0 \%$ nitrate nitrogen $\left(\mathrm{NO}_{3}-\mathrm{N}\right) ; 0.0 \%$ carbamide nitrogen $\left(\mathrm{NH}_{2}-\mathrm{N}\right) ; 3.0 \%$ phosphate $\left(\mathrm{P}_{2} \mathrm{O}_{5}\right)$ soluble in neutral ammonium citrate and water; $2.4 \%$ phosphate $\left(\mathrm{P}_{2} \mathrm{O}_{5}\right)$, water soluble; $20.0 \%$ potassium oxide $\left(\mathrm{K}_{2} \mathrm{O}\right)$, water soluble; $2.0 \%$ total magnesium oxide $(\mathrm{MgO})$; 
$1.6 \%$ magnesium oxide $(\mathrm{MgO})$, water soluble; $10.0 \%$ total sulphur $(\mathrm{S}) ; 8 . \%$ sulphur $(\mathrm{S})$, water soluble; $0.02 \%$ total boron $(\mathrm{B}) ; 0.0 \%$ total copper $(\mathrm{Cu}) ; 0.06 \%$ total iron $(\mathrm{Fe}) ; 0.0 \%$ total manganese $(\mathrm{Mn}) ; 0.01 \%$ total zinc $(\mathrm{Zn}) ; 0.8 \%$ nitrification inhibitor 3.4-dimethylpyrazole-phosphate (DMPP) related to total of $\mathrm{NH}_{4}-\mathrm{N}$ and $\mathrm{NH}_{2}-\mathrm{N}$; low in chlorine $(\mathrm{Cl})$.

Physical properties: 1, physical appearance: solid, granulated; 2, colour: purple; 3, bulk density: $1,250 \pm 100 \mathrm{~kg} / \mathrm{m}^{3} ; 4$, granulometry: $90 \%=2-4 \mathrm{~mm} ; 5$, average granule size (d50): $3.2 \pm 0.4 \mathrm{~mm} ; 6, \mathrm{pH}$ (1:10 in water): 4.5-5.5 (URL $\left.{ }^{1}\right)$.

Leaf- and stem samples were dried at $70{ }^{\circ} \mathrm{C}$. The air-dry samples were thoroughly minced. For elemental studies powdered samples were digested in a microwave device by means of concentrated nitric acid and hydrogen peroxide (Milestone Ethos Plus). Main macro element content was measured by optical emission spectrometer (ICP-AES method) (HÜVELY, 2005). Nitrogen content in leaf and stem were determined using the Kjeldahl method after sulphuric acid digestion (FOSS Kjeltec 2300). Macro element (N, P, K, Ca, $\mathrm{Mg}, \mathrm{Na}$ ) contents were calculated in $\mathrm{m} / \mathrm{m} \%$ dry matter.

The required tests were made according to the regulation include measurement of the $\mathrm{N}, \mathrm{P}$, $\mathrm{K}, \mathrm{Ca}, \mathrm{Mg}$ content.

\section{RESULTS}

Fresh weight and dry weight values of fenugreek are illustrated in Figure 1. The highest value $(14.45 \mathrm{~kg} / \mathrm{plot})$ for the measurement of the fresh weight of $T$ foenum-graecum was $300 \mathrm{~kg} /$ ha treatments. The $150 \mathrm{~kg} /$ ha fertilizer dose (Treatment 1) showed the lowest fresh weight value $(7.8 \mathrm{~kg} / \mathrm{plot})$. The highest dose of treatment $(450 \mathrm{~kg} / \mathrm{ha})$ resulted in a decrease in the amount of fenugreek (fresh and dry weight as well). Dry matter content of the plants has also decreased. 


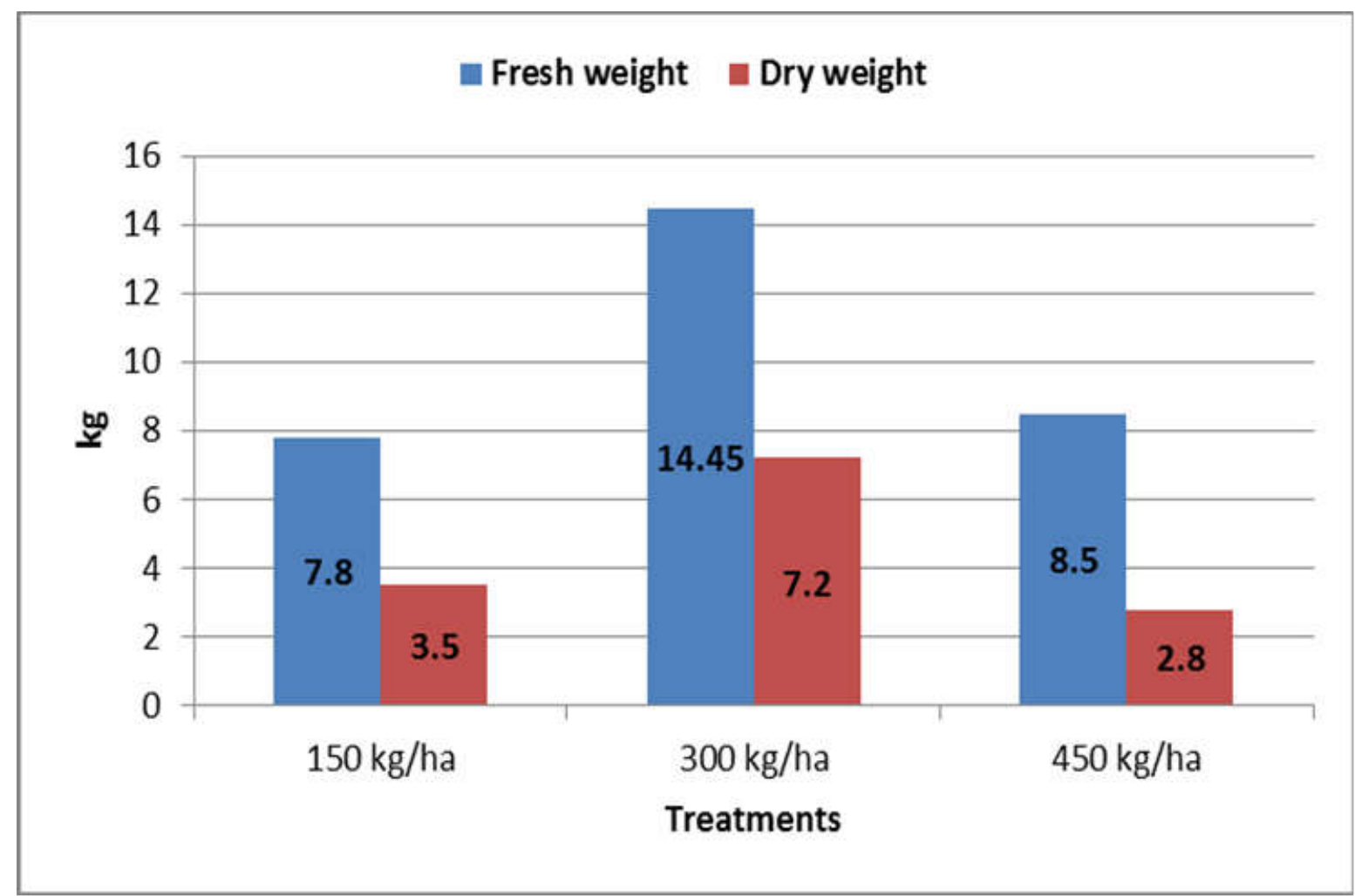

Figure 1. Fresh mass (kg) and dry mass (kg) characteristics of Trigonella foenumgraecum

The spring-type T. foenum-graecum can be harvested in 80-90 days after seeding (Figure 2).

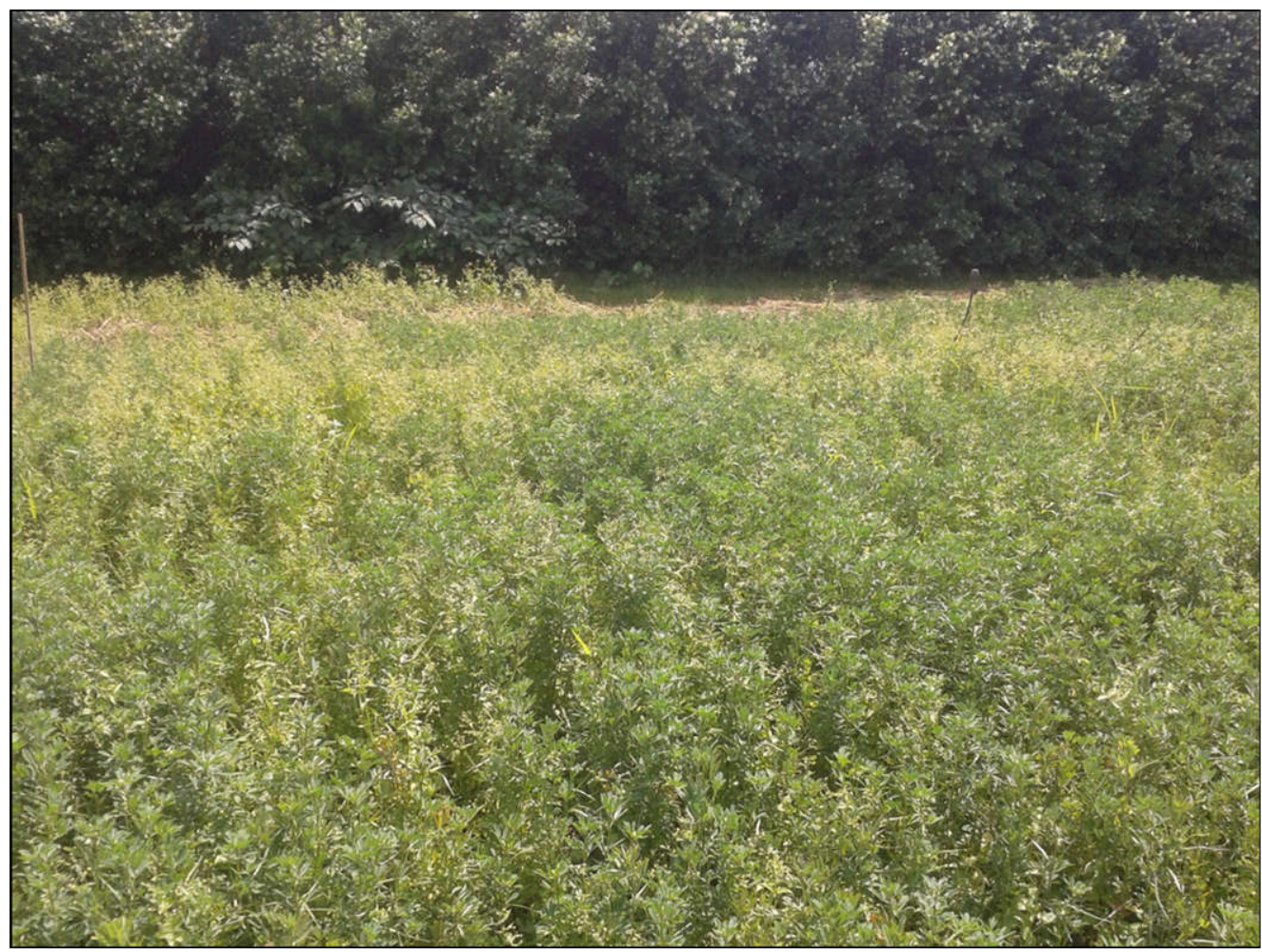

Figure 2. Fenugreek stock on $4^{\text {th }}$ of June 2018 
Review on Agriculture and Rural Development 2019 vol. 8 (1-2) ISSN 2677-0792

The harvest was at the end of June and early July, when the biomass was recorded (Figure $3)$.

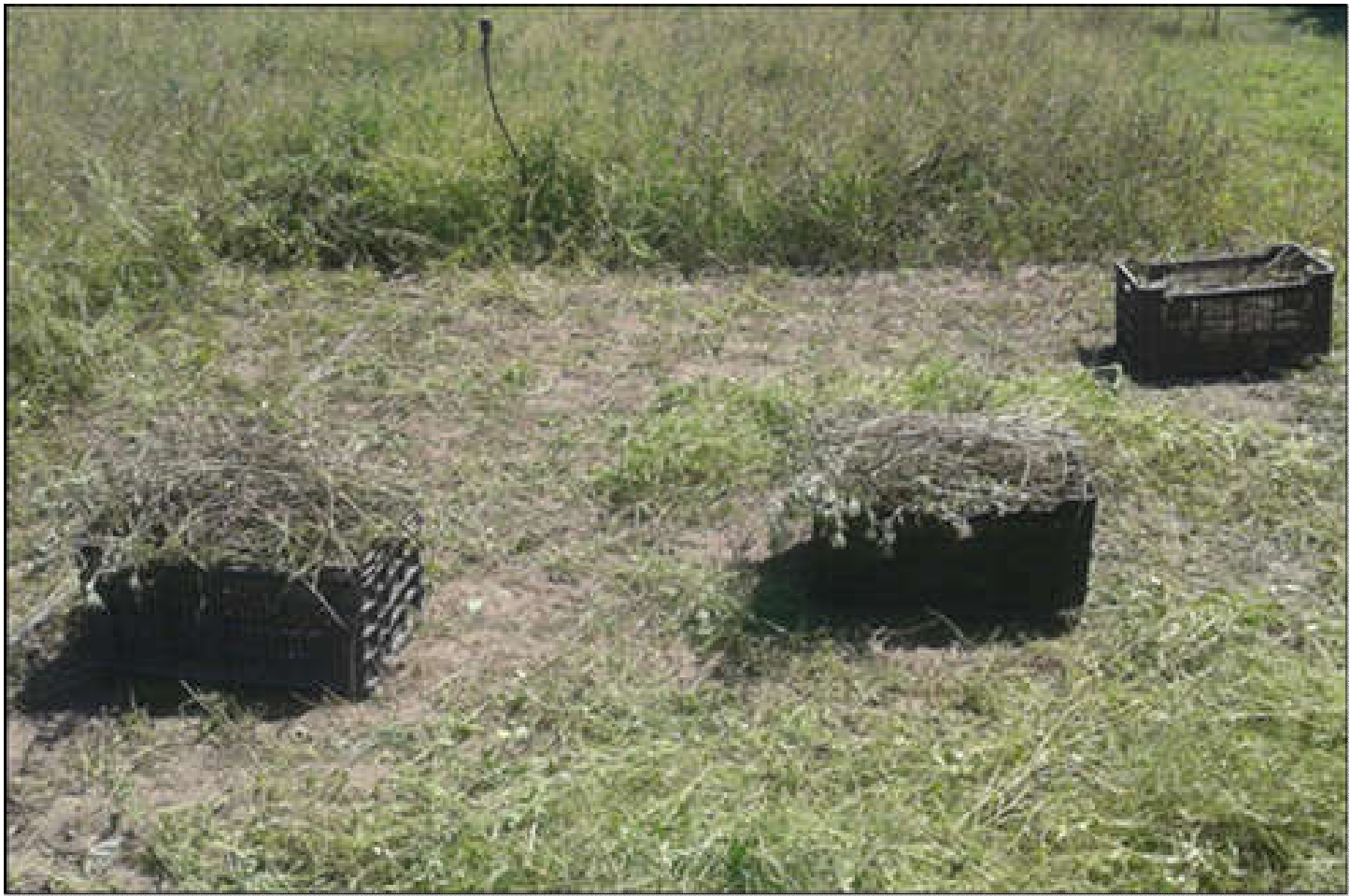

Figure 3. The harvest of fenugreek ( $3^{\text {th }}$ July 2018)

During the study we determined the concentration of some nutrients (nitrogen, magnesium, calcium, potassium and phosphorus) of fenugreek in the parts of the plants above the ground (stem, leaf) (Figure 4).

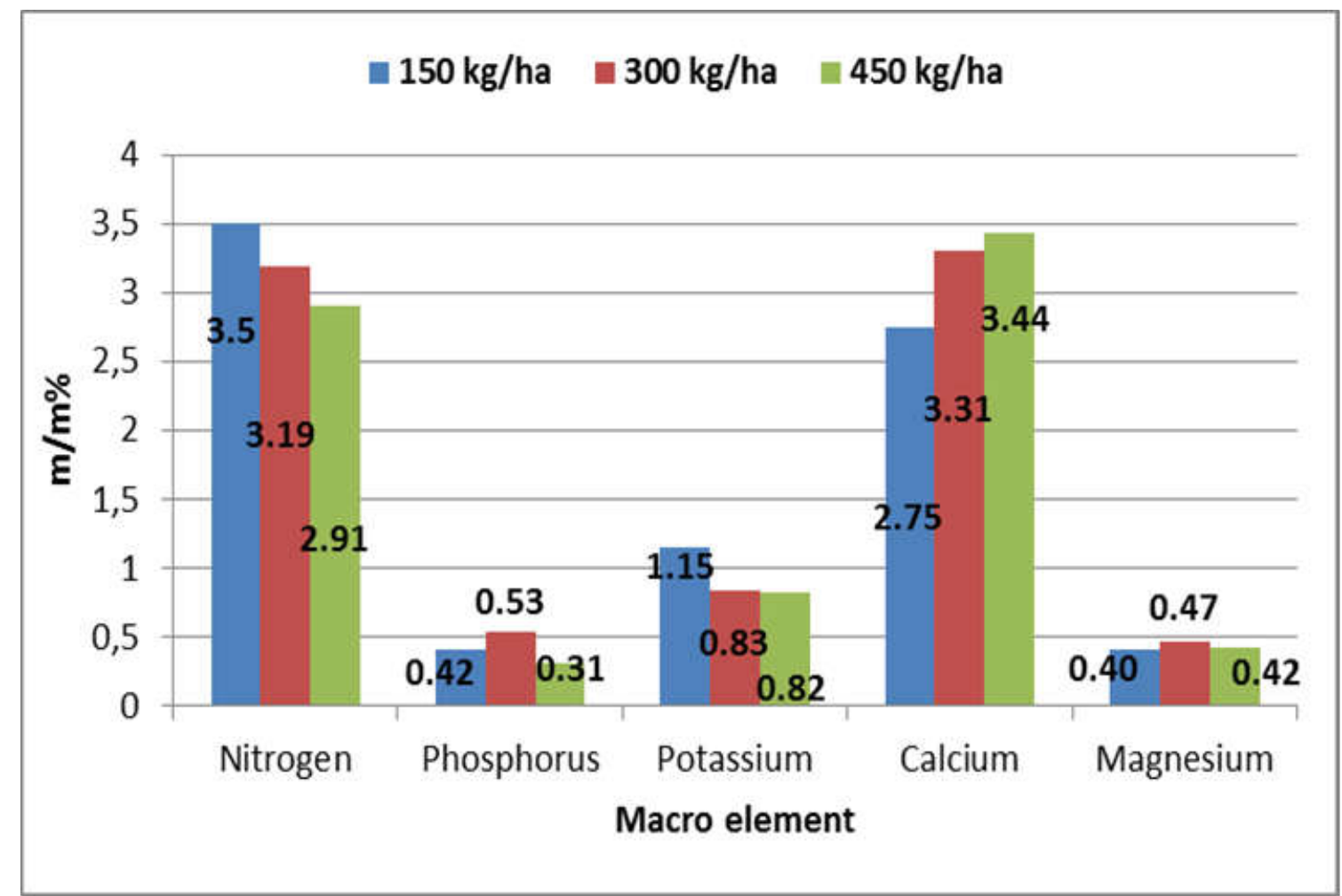

Figure 4. Macro element (N, P, K, Ca, Mg, Na) contents were calculated in $\mathbf{m} / \mathbf{m} \%$ dry matter 


\section{CONCLUSIONS}

As a result of Treatment $3(450 \mathrm{~kg} / \mathrm{ha})$, the biomass of fenugreek has decreased (wet and dry weight). In order to interpret the effects, we will continue our investigations in the future.

The highest yield of Trigonella foenum-graecum was achieved by Treatment 2 (300 $\mathrm{kg} / \mathrm{ha})$, both in terms of fresh weight $(14.45 \mathrm{~kg})$ and dry weight $(7.2 \mathrm{~kg})$.

The content of calcium in dry matter $(\mathrm{m} / \mathrm{m} \%)$ increased linearly from Treatment 1 (150 $\mathrm{kg} / \mathrm{ha})$ to Treatment $3(450 \mathrm{~kg} / \mathrm{ha})$ in the examined fenugreek stem and leaf.

In the tested $T$. foenum-graecum plants, nitrogen and potassium contents of air-dry substance $(\% \mathrm{~m} / \mathrm{m})$ decreased steadily by increasing the fertilizer doses from $150 \mathrm{~kg} / \mathrm{ha}$ to $450 \mathrm{~kg} / \mathrm{ha}$.

After the initial growth, phosphorus and magnesium concentration decreased with the increasing fertilizer use. Our results suggest that the highest fertilizer treatment resulted in general lower nutrient levels in Trigonella foenum-graecum biomass. In our study, 300 $\mathrm{kg} /$ ha fertilizer dose had beneficial effects on biomass production and nutrient contents as well.

\section{ACKNOWLEDGEMENTS}

We thank the support of research that "Development of functional, healthy and safe food product chain model based on the principle table, thematic research networks from the field," the EFOP-3.6.2-16-2017-00012 realized under the project of the John von Neumann University.

\section{REFERENCES}

HüVEly, A. (2005): Az ICP, vagyis az emissziós analízis lehetőségei címü előadás/ A Magyar Tudomány Ünnepe, Megyei Tudományos Fórum/ Kecskeméti Főiskola/ Kertészeti Főiskolai Kar/ Kecskemét. pp. 102-105.

KALMÁR, É.A. (1999): A görögszéna (Trigonella foenum-graecum L.) beltartalmi értékének és silózhatóságának vizsgálata. Diplomamunka, University of Pannonia, Mosonmagyaróvár. pp. 20-26.

MAKAI, P.S., MAKAI, S. (2004): Görögszéna (Trigonella foenum-graecum L.) fajták terméseredményeinek összehasonlítása és az optimális csíraszám meghatározása. Acta Agronomica Óvariensis 46(1): 17-23.

MAKAi S., PÉCSI, S., KAJDI, F. (1996): A görögszéna (Trigonella foenum-graecum L.) termesztése és hasznosítása. Környezet- és Tájgazdálkodási Füzetek 4: 32-35.

MÁTHÉ, I. (1975): A görögszéna. Magyarország Kultúrflórája. Akadémiai Kiadó, Budapest. 2: 5-50.

Provorov, H.A. (1985): Izomencsivoszty rasztenij nazsitnyika grecseszkovo (Trigonella foenum-graecum L.) po szpaszbnosztyik szimbiozusz klubenkovümi bakterijami lucernü Buluten vszecajuznovo naucsno-Isszledovatyelszkovo Insztiuta Szelszkohozjajszvennoj Mikrobiologii 41: 21-213.

SALVATORE, D.G. (1951): Ricerhe sui consumi idrici e indogini sull autofertilita del feno greco stazione. Agraria Sperimentale Bari. pp. 1272-1286.

VAN WYK, B.E. (2005): Handbuch der Nahrungspflanzen. Wissenschaftliche. Verlagsgesellschaft, Stuttgart. pp. 15, 367.

VARGA, R. (2001): A görögszéna (Trigonella foenum-graecum L.) termelésének jelentősége. Diplomamunka, Szent Istvan University, Gödöllő. pp. 35-42. 